\title{
新規開発地の動く歩道の適切性についての研究 *
}

Study for suitability of moving walk at newly developed*

\section{大東延幸** · 原田 昇***.太田勝敏**** \\ By Nobuyuki OHIGASHI **, Noboru HARATA***and Katutoshi OHTA ****}

\section{1. 本論の背景と目的}

\section{（1）新規大規模開発地内外の \\ 歩行者交通についての問題点}

大都市およびその近傍では、埋め立て地や工場の 跡地の転用等による、まとまった広さがある新規開 発地（以下本論では開発地と略す）が増えつつある。 この様な事例において、開発地の利用者の開発地内 外の歩行距離を検証すると、

(a)開発地の外部では、その開発地までのアクセス交 通手段を既存の鉄道等の大量輸送機関に頼っている ところは多い。しかし、開発地が後から作られた場 合、そのアクセスを担う鉄道駅等は必ずしも開発地 の中に有るか隣接しているとは限らず、駅等と開発 地の距離が歩行距離としては長い場合がある。

(b)開発地の内部では、その開発地が幾つかの大型の 建物群で構成される場合には、敷地の区画が既存の 地区の場合より大きい場合が多く、開発地内の歩行 距離としては長い場合がある。

上記の(a)(b)の様な場合、開発地では、歩行距離の 短縮ばかりでなく歩行空間を質的に向上させて、利 用者の心理的 ·肉体的に距離抵抗を減らす工夫が考 えられる。例えば、ペデストリアンデッキを設けて 階段の昇り降りや段差を隇らしたり、更にバスや動 く歩道等の短距離交通機関を導入することによって、 歩行距離そのものを短くする可能性もある。

*キーワード：地区交通計画 歩行者・自転車交通計画 $* *$ 正員、工修、広島大学大学院国際協力研究科

（東広島市鏡山1-4-1 TEL\&FAX 0824-24-7849）

***正員、工博、東京大学工学部都市工学科

（東京都文京区本郷7-3-1 TEL\&FAX 03-5800-6958）

****正員、Ph.D、東京大学工学部都市工学科

（東京都文京区本郷7-3-1 TEL\&FAX 03-5800-6958）

\section{（2）開発地の内容と短距離交通の特性の関係}

開発地の内容が業務目的主体であれば、その利用 者はある程度特定されると考えられ、利用者の開発 地内外での歩行目的も通勤・業務が多いと考えられ る1)。更にその交通需要にもピークが大きいと考え られ、歩行距離そのものを短くするための短距離交 通機関としては、装置設置型の動く歩道よりバスの ような需要変動に対応できるものの方が現実的であ る可能性が高い。実際、路線バスの運行経路を開発 地内 ${ }^{2)}$ に取り込んだ事例がある。

しかし、開発地の内容が商業目的主体であれば、 その利用者は不特定多数が対象であり、利用者の開 発地内外での交通需要にもピークが少ないと考えら れる。商業的なイメージアップの目的もあり、歩行 距離そのものを短くするための短距離交通機関とし ては、待ち時間のない動く歩道を導入する可能性が 業務主体の開発地より高いと考えられ、実際、動く 歩道を導入した事例が見られる。しかし、この様に 歩行者空間を質的に向上すればするほどその設置に は費用がかかり、特にエスカレーターや動く歩道の ような装置設置型の短距離交通機関は、更に多額の 運行費用 ${ }^{3)}$ が必要でありその導入事例は多くない。

これまでの研究から、商業目的主体の開発地に導 入された動く歩道について、導入の費用は開発と一 体的に出され、運行費用は他の施設の光熱費等と同 様に拠出され最終的には個々のテナントの負担となっ ている事例が大半であっだ)。しかし開発者が動く 歩道を導入する理由として挙げたものに、利用者の 「快適性」「利便性」の向上という理由が多く見ら れた。これは開発者が単に距離が長いという理由だ けでは高価な動く歩道の導入は難しく、動く歩道の 導入でその歩行者施設、更に開発地全体の「快適性」 や「利便性」が向上すると判断できない限り動く歩 道は導入できないと判断していると考えられる。 


\section{（3）本論の目的}

本論は動く歩道が導入された前記の(a)(b)の様な商 業目的の開発地を対象として、利用者が最寄り駅と 開発地の間の距離をどう意識しているかを検討し、 動く歩道と、その代替案の短距離交通機関として他 の開発地で導入事例のあるバスについて、所要時間 と費用について比較を行い、次に対象開発地で行っ たアンケート調査から、開発者が動く歩道を導入す る理由として挙げた、利用者の「快適性」「利便性」 が実際に意識されているかを検討し、対象開発地に 動く歩道を導入したのが適切かどうか考察すること を目的とする。

\section{（4）対象とした開発地の概要}

本論では検討する開発地として、広島市内の商業 施設「アルパーク」を対象とした。ここは、広島市 の副都心をめざして作られた埋め立て地に立地した 商業施設であり、前記の(a)(b)の様な商業目的の開発 地の条件を満している。この商業施設と、最寄り鉄 道駅で隣接している J R 山陽本線新井口駅・広島電 鉄商工センター入口駅の間は最短で約 $250 \mathrm{~m}$ 離れてい る。両鉄道駅と商業施設の間には、屋根付きのペデ ストリアンデッキが広島市によって整備されており、 両者は同一レベルで結ばれており、途中3本の動く歩 道が商業施設の開発者によって設置されている。そ の概要は表1のとおりである。

表1 対象とした開発地に導入された動く歩道の概要

\begin{tabular}{|l|l|}
\hline 幅 & $1.3 \mathrm{~m} 、$ 人が 2 人並べる幅 \\
\hline 長さ & $40 \mathrm{~m}, 70 \mathrm{~m}, 21 \mathrm{~m}$ が往復各 1 本ずつ \\
\hline 運行時間 & 鉄道の始発から終電まで \\
\hline
\end{tabular}

\section{2. 対象とした開発地における}

\section{動く歩道とバスの比較}

\section{（1）動く歩道とバスの所要時間}

対象開発地と最寄り鉄道駅を結ぶペデストリアン デッキの長さは約 $250 \mathrm{~m}$ であり、そのうち $131 \mathrm{~m}$ に動 く歩道が設置されている。したがって約 $120 \mathrm{~m}$ は徒歩 で歩くこととなるが、歩く速さを $4 \mathrm{~km} / \mathrm{h}$ とると約 1.8 分の時間がかかる。動く歩道を利用している時間
表2 利用形態別の速さと所要時間

\begin{tabular}{|l|l|l|l|}
\hline \multirow{2}{*}{} & \multicolumn{2}{|l|}{ 動く歩道を利用する } & \multicolumn{1}{c|}{$\begin{array}{l}\text { 動く歩道を } \\
\text { 利用しない }\end{array}$} \\
\cline { 2 - 3 } & \multicolumn{1}{|l|}{ く } & 立ち止まる & \\
\hline 速さ & 約 $6 \mathrm{~km} / \mathrm{h}$ & 約 $2 \mathrm{~km} / \mathrm{h}$ & 約 $4 \mathrm{~km} / \mathrm{h}$ \\
\hline 所要時間 & 約 1.3 分 & 約 4.0 分 & 約2.0分 \\
\hline
\end{tabular}

はその利用形態、すなわち動く歩道の上で歩くか立 ち止まるかによってかわる。動く歩道の速さは約 $2 \mathrm{~km} / \mathrm{h}$ であるのでそれぞれの利用形態の所要時間は表 2の様になる。従って、動く歩道を利用した場合の総 所要時間は、約 3.1 分 $~ 5.8$ 分かかり、動く歩道を利用 せずに全て歩いた場合には約3.8分の時間がかかる。

施設管理者によると、現在の利用者数では平日・ 祭日共に、渋滞等で利用者が必ず動く歩道上で立ち 止まらなければならない状態は年に数回程度である。 また同時に動く歩道の利用状況を調査したが、渋滞 等で利用者が必ず動く歩道上で立ち止まらなければ ならない状態は観測されなかった。その際の断面交 通量に対する動く歩道上で立止る人数と動く歩道上 で歩く人数の割合は、 $4 \%$ と $83 \%$ で残りの $13 \%$ のは 動く歩道を利用していなかった。動く歩道の上で歩 いている人が全て一度も減速せずに歩いたとは考え られないが、仮にこの割合で動く歩道の利用者の平 均時間を計算すると約 3.78 分となり、動く歩道を利用 せずに全て歩いた場合の3.8分とほほ等しい。従って このペデストリアンデッキの平均利用時間は約 3.8 分 程度と考えられる。

一方、対象開発地と最寄り鉄道駅を結ぶペデスト リアンデッキの下には、2車線の幹線道路があり、そ のままバスを運行することは不可能ではない。ここ にバスを運行すると想定すると、建物配置の関係か ら約 $400 \mathrm{~m}$ の距離になる。乗り降りに約 1 分ずつかか り、走行時間は約 1.5 分と考えられるので合計約 3.5 分 の時間が必要であると考えられる。しかし、この場 合バスの待ち時間が必要であり、道路渋滞や往復す るためにバスが反対側車線に出ることも考慮すると、 動く歩道付きのペデストリアンデッキを利用するよ り所要時間がかなり長くなることが予想される。

\section{（2）動く歩道とバスの導入・運営に必要な費用}

調査対象地の施設管理者の発表によると、歩行者 
専用通路を使う人数は 1 年を通して平均で1日当たり 約 8,000 人であった。

動く歩道の運行費用としては動力費と維持費が考 えられる。調査対象地の動く歩道の運行費用を知る ことはできなかったが、一般的な費用から計算する と、動力代は、 $1 \mathrm{~m}$ 当たりの電力消費量が $0.1 \mathrm{kw} / \mathrm{h}$ 、 電気代が $1 \mathrm{kw} / \mathrm{h}$ たり 14.19 円、鉄道駅の始発から終電 まで1日 18 時間運行しており、1カ月30日で $131 \times 2 \times$ $0.1 \times 14.19 \times 18 \times 30=200,760$ 円、となる。

月に1回の維持費用は、一般的な維持費用から計算 すると、動く歩道1本あたりの基本維持費用が70,000 円で70,000円 $\times 6$ 本 $=420,000$ 円、基本以外の維持費用 として $10 \mathrm{~m}$ 以上につきその維持費用が $1 \mathrm{~m}$ あたり 2,000 円なので、 2,000 円 $/ \mathrm{m} \times(262-6$ 本 $\times 10) \mathrm{m}=824,000$ 円と なり合計 1 月あたり約100万円となる。

動く歩道の建設の費用は同様に、1 mあたり200万 円で、 200 万円 $/ \mathrm{m} \times 262 \mathrm{~m}=$ 約 5 億2000万円となる。

バスの場合、まず必要なバスの台数であるが、1日 当たり約 8,000 人の利用客があるが、これは対象開発 地と最寄り鉄道駅の間の往復の利用客であるので、 片道は 1 日当たり約 4,000 人となる。この約 4,000 人が、 鉄道駅の始発から終電まで1日18時間ではなく、仮に 商業施設の開店時間の一日10時間に集中したとして も、一般的な大型バス（80人乗り）なら一台で輸送 できる。

従って、バスの運行費用は、他の商業用施設の送 迎用バスの例から1日約4万円、1カ月あたり約 120 万 円程度で運行できると推定される。バス導入の費用 は冷房付きの大型バスの場合約2,500万円程度である。

\section{（3）動く歩道とバスの比較と考察}

対象とした開発地で、最寄り鉄道駅を結ぶ短距離 交通機関として動く歩道とバスについて比較した場 合、所要時間の点では、動く歩道が有利であり、費 用の内、運行費用はバスの方が2割ほど高いことがわ かった。しかし、動く歩道とバスそのものの費用の 差は約5億2000万円と2500万円で約20倍の差がある。 設備費と運行費の和が同じになるのは、1年間の動く 歩道の運行費は（2）の計算より約1200万円で、同様 にバスの運行費用は約 1440 万円で一年あたりバスの 方が約140万円高い。従ってこの運行費の差で、設備
費の差が埋まるのは、単純に計算しても（5億2000万 円-2500万円）/140万円=約 350 年となりこれは現実的 な年数ではない。

しかしペデストリアンデッキ下の道路は、交通量 の多い幹線道路であり、現実問題として短距離のバ ス輸送が行えるかどうか疑わしい。仮にペデストリ アンデッキにバス専用道路を併設すると、その費用 は約10億円と試算され、動く歩道の建設費用の約 5 億 2000万円より高くなる。従って、バスのスムーズな 運行まで考慮しバス専用の運行空間を確保すれば、 バスを運行するための施設を建設する費用が、動く 歩道の建設の費用より多くなると考えられる。しか も対象とした開発地では、動く歩道の方が待ち時間 や乗り降りの点でバスより優れていると考えられる。

\section{3. 対象とした開発地の利用者の意識}

\section{（1）アンケート調査の構成と主旨}

今回行ったアンケート調査の主な構成は、利用者 の属性・ペデストリアンデッキへの利用者の意識 · 動く歩道への利用者の意識と利用形態であり、設問 は全部で25問で、大半の設問を調査対象者が答えや すいように 5 段階の序列変数で構成した。調查の概 要を表3に、アンケート数と抽出率を表4に示す。

表3 調査の概要

\begin{tabular}{|c|c|}
\hline 調査日 & 1995年10月26日（木） 10月29日（日） \\
\hline 調査 & 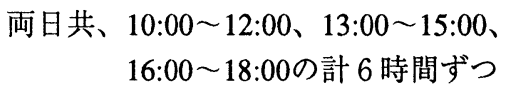 \\
\hline 調査対象 & $\begin{aligned} \text { ペデストリアンデッキと } \\
\text { 動く歩道の利用者 }\end{aligned}$ \\
\hline 調査方法 & $\begin{array}{c}\text { 調査員による質問聞き取り } \\
\text { アンケート調査 }\end{array}$ \\
\hline
\end{tabular}

表4 アンケート調查数

\begin{tabular}{|c|c|c|c|}
\hline \multicolumn{2}{|c|}{26 日 } & \multicolumn{2}{c|}{29 日 } \\
\hline アンケート数 & 断面利用者数 & アンケート数 & 断面利用者数 \\
\hline 175人 & 6085 人 & 183人 & 9821 人 \\
\hline 抽出率 & $2.8 \%$ & 抽出率 & $1.9 \%$ \\
\hline
\end{tabular}

2章の考察から、対象とした開発地の場合では単に 必要な輸送力を確保するだけでなく、待ち時間や乗 
り降りの点を考慮した利用者の快適性・利便性まで 考えると、バスより動く歩道の方が費用が少ないと 考えられた。開発者も動く歩道の導入理由に利用者 の快適性・利便性が向上することをあげている。そ こで本章では利用者が動く歩道によって「快適性」 や「利便性」が高いと意識しているかどうかを検証 した。「快適性」「利便性」という言葉の定義は曖 昧で必ずしも互いに独立した概念では無いと考えら れるが、本論ではこれまでの検討から、「快適性」 を精神的な楽さ、「利便性」を具体的な時間短縮が ある等の肉体的な楽さと定義し、本アンケート調査 でも聞き取りの際、調査員がその点を説明して調査 を行った。なお調查の際、ペデストリアンデッキと いう言葉がまだ一般的でないと考えられたので、通 路という言葉を用いた。以下本論ぺデストリアンデッ キを通路とも記する。

\section{（2）アンケート調査の結果}

アンケート調査の項目の内、対象とした開発地の ペデストリアンデッキ（通路）と動く歩道の、長さ に対する意識と「快適性」「利便性」に関する項目 について、図1から図6に示す。



図1通路の長さについての意識



図2もし動く歩道が無かったら通路の長さをどう思うか

図1より通路の長さはふつうと感じている人が最も 多い。しかし図2より、もし動く歩道が無ければの通 路の長さをどう感じるかについては、長いと感じる 人が最も多く、やや長いと感じる人も含めると 8 割 であり、利用者は最寄り鉄道駅と開発地の間の距離 を歩くには長いと感じていると考えられる。

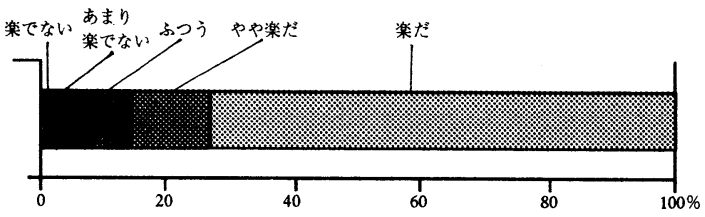

図3通路の快適性についての意識



図4 通路の利便性についての意識

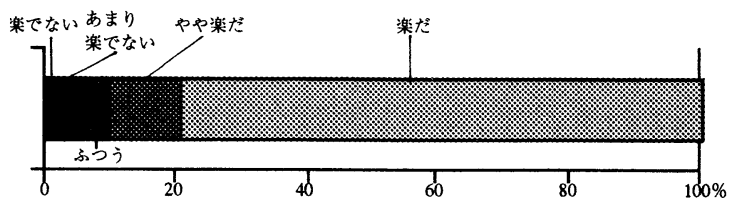

図5動く歩道の快適性についての意識

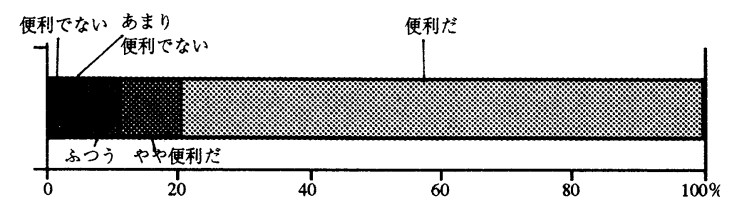

図6 動く歩道の利便性についての意識

図5の動く歩道の快適性・図6の動く歩道の利便性 はともに高いと感じている人が多く、いずれも図 3 の 通路の快適性・図4の通路の利便性を上回っている。

\section{（3）動く歩道の利用意識に関する因果構造分析}

アンケート調査の結果から利用者はペデストリア ンデッキと動く歩道に対して共に「快適性」「利便 性」について意識していると考えられる。しかし 「快適性」「利便性」は共に主観的な概念であるの で、これをアンケートで調査した客観的な項目との 因果関係を説明するため、因果構造分析を行った。

調査の項目の中で、「快適性」「利便性」に影響 を与えている項目は、利用者の感じている通路の長 さ・幅、動く歩道の速さ・長さ等であると考えられ る。また、利用者の属性や開発地への来訪に関する 項目も「快適性」「利便性」に影響を与えていると 考えられるが、単純集計の結果からはその影響が明 確でなかった。そこで利用者の客観的な要因で説明 される「動く歩道の有効性」という概念を仮定した。 逆に、本アンケート調査の調査項目の中で「動く歩 道の有効性」が影響を与える要因は利用者に重い荷 




図7本論で仮定したパスダイヤグラム



図8ＬISREL用パスダイヤグラム
物の有る場合と無い場合に、動く歩道を利用するか どうか、であると考えられる。また、もし動く歩道 がないと仮定した場合に通路の長さをどう思うか、 という調査項目は、「動く歩道の有効性」「快適性」 「利便性」のいずれにも影響を及ぼすものと考えら れる。

これら相互の因果関係を求め、動く歩道の利用意 識に関する因果構造分析を行なうため、図7のような パスダイアグラムを仮定し、実際の計算はLISRELと いうパッケージを用い、「動く歩道の有効性」「快 適性」「利便性」を潜在変数として推定を行った。 パスダイアグラムの中で楕円が潜在変数、四角が観 測変数、矢印の方向が因果関係の方向を示す。図7で は潜在变数に内生潜在変数しか考慮しておらず、外 生潜在変数が考慮されていないため、こののままで は、LISRELでの解析を実行できない。そこで外生潜 在変数として「利用者の属性」と「通路・動く歩道 についての利用者の意識」を置いた、動く歩道の利 用意識に関する因果構造分析のパスダイアグラムを 図8に示す。

\section{（4）推定結果と考察}

因果構造分析の推定結果について表5に示す。 各パラメータのパスが大きいほど因果関係が大きい ことを示し、符号が負ならば仮定した因果関係が逆 であったことを示す。

個々の変数の分析結果からいえることは、まず 最寄り鉄道駅と開発地の間の距離について、 $\lambda_{\mathrm{x} 71}$ と $\lambda_{\mathrm{x} 72}$ の值から、両方ともパラメー夕推定值が負であ る。それを考慮し 2 つを比較すると、もし動く歩道 がない場合にこの通路の長さをどう感じるかという 調査項目は、「利用者の属性」と「通路・動く歩道 についての利用者の意識」から同じょうに影響を受 けているので、利用者が一様にこの距離を歩行距離 として長いと感じていると考えられる。

$\lambda_{\mathrm{y} 11}$ と $\lambda_{\mathrm{y} 21}$ から、重い荷物の有る場合に動く歩道 を利用することが「動く歩道の有効性」との関係は 強く、また $\gamma_{11}$ から「利用者の属性」は「動く歩道の 有効性」に強い因果関係があると考えられる。この ことは、商業目的主体の開発地にとっては、動く歩 道の存在が有効に働いていると考えられる。 
表5 推定結果

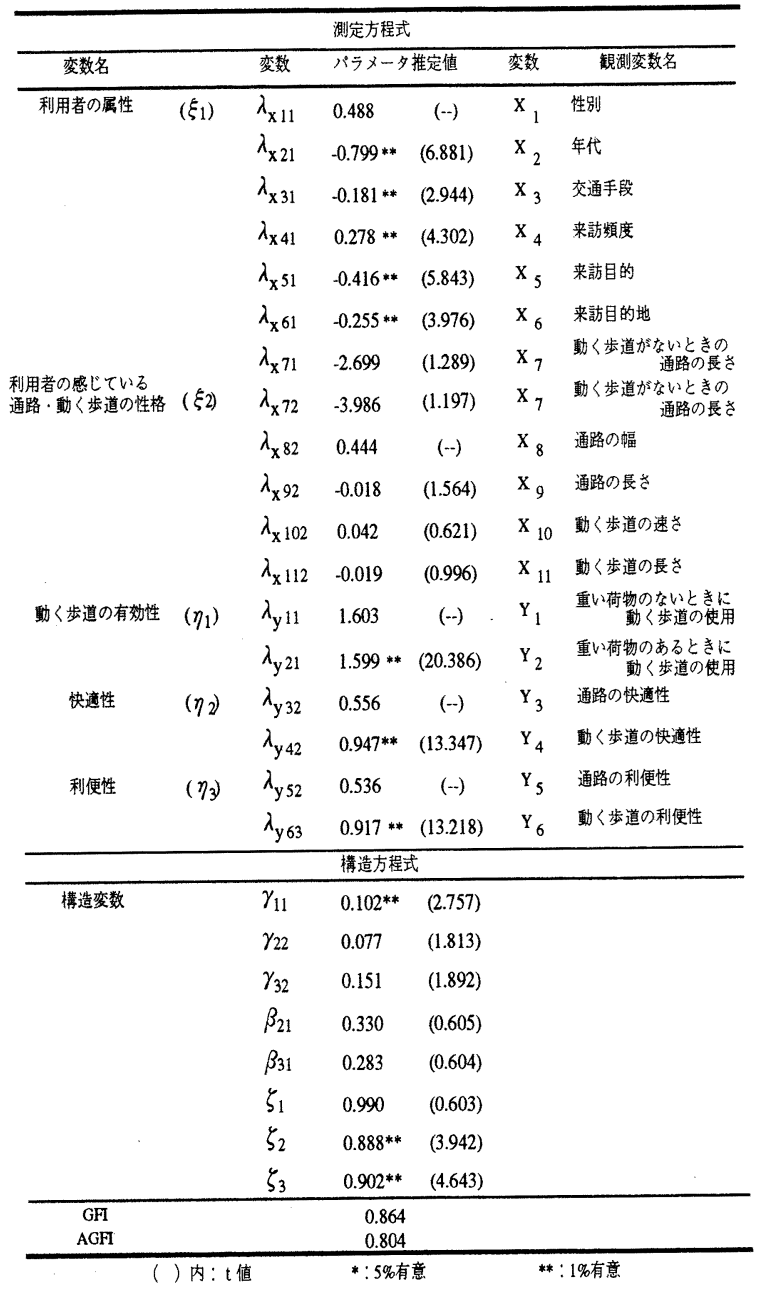

利用者の通路の動く歩道に対する「快適性」「利便性」 に対する意識については、 $\lambda_{\mathrm{y} 32}$ と $\lambda_{\mathrm{y} 42}$ から、動く歩道 の「快適性」は通路の「快適性」よりも大きな值となっ ている。つまり利用者は動く歩道が快適であれば通路も 快適であると考えている。また $\lambda_{\mathrm{y} 53}$ と $\lambda_{\mathrm{y} 63}$ より「利便 性」についても同様のことが考えられ、対象とした開発 地の利用者は、通路の動く歩道の「快適性」「利便性」 を意識していると考えられる。

\section{4. 結論}

今回対象とした商業施設主体の開発地では、最寄り鉄 道駅と開発地の距離は、利用者から長いと感じられてい る。この距離を補助する短距離交通機関として、対象開 発地では動く歩道が導入されているが、代替案としてバ スと比較した場合、所要時間・待ち時間・乗り降りのし やすさ等では動く歩道が優れている。現状の利用者数を 輸送する場合、運行費用は、バスの方がやや高い程度で あるが、設置費用は動く歩道の方が決定的に高い。しか しバスは既存の道路を利用せず、スムーズな運行を確保 するために専用空間を確保すると、動く歩道を設置する より費用が必要である。

開発者が動く歩道の導入理由として挙げている動く歩 道の「利便性」「快適性」は利用者に意識されており、 代替案としてバスと比較した場合、動く歩道の特性が優 れていることも合わせて考えると、対象開発地に動く歩 道を導入したことは適切であったと考えられる。

今回対象とした開発地は、前記の(a)(b)の様な商業目 的の開発地として典型的なものを選んだが、今後は同様 な開発地の事例についても考察し、開発地へ短距離交通 機関を導入する際の指針を求める必要があると考える。

\section{参考文献}

1)小沢英幸 - 棒澤芳雄 - 小山 茂・清原航也：業務地区 に おける歩行者空間の施設整備に関する基礎的研究、土木計 画学研究・講演集No.17,pp.603-605,1995

2)高石光博 - 棒澤芳雄 - 小山 茂：業務地区における通 勤 者の歩行特性に関する研究、土木計画学研究・講演 集No.19

(2) ,pp.477-480,1996

3)大東延幸 ·原田 昇・太田勝敏 : 公共的空間に導入さ れ た短距離交通機関についての研究、土木計画学研究・謐演 集No.16(1),pp.249-254,1993

4) 大東延幸・原田 昇・太田勝敏: 大规模開発地の端末 交 通についての研究、土木計画学研究・講演集

No.17,pp.599-603,1995 
新規開発地の動く歩道の適切性についての研究

大東延幸・原田 昇・太田勝敏

本論は、動く歩道が導入された商業目的の新規大規模開発地を対象事例として、動く歩道と、 その代替案の短距離交通機関として他の開発地で導入事例のあるバスについて、所要時間と費用 について比較を行い、次に対象開発地で行ったアンケート調査から、開発者が動く歩道を導入す る理由として挙げた、利用者の「快適性」「利便性」が実際に意識されているかを検討した。そ の結果、利用者は動く歩道の「利便性」「快適性」を意識しており、代替案としてバスと比較し た場合、動く歩道の特性が優れていることも合わせて考えると、対象開発地に動く歩道を導入し たことは適切であったと考えられた。

Study for suitability of moving walk at newly developed

Nobuyuki OHIGASHI , Noboru HARATA and Katutoshi OHTA

This paper aims to empirically investigate the applicability of a moving side walk in newly developed commercial district. A questionnaire survey was carried out for some people in newly developed in Hiroshima City.

It was found that the actual pedestrian facility was not sufficiently developed in the district. The survey results also indicated that a moving side walk would be difficult to introduce in that district because of the limitation of law and planning process. 